\title{
Unique variant of dual left anterior descending artery
}

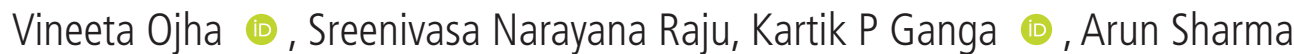

Department of Cardiovascular Radiology and Endovascular Interventions, All India Institute of Medical Sciences, New Delhi, India

Correspondence to Dr Arun Sharma; drarungautam@gmail.com

Accepted 13 March 2020

\section{DESCRIPTION}

CT angiography in a 45-year-old woman with atypical chest pain revealed two left anterior descending (LAD) arteries in the anterior interventricular sulcus (AIS). The longer LAD (white arrowhead in figure $1 \mathrm{~A}-\mathrm{D}$ ) was arising from the left main coronary artery (LMCA) and was coursing up to the apex of the left ventricle. The shorter LAD (white arrow in figure $1 \mathrm{~A}-\mathrm{D}$ ) was arising from the right coronary sinus, taking a trans-septal intramyocardial course to finally accompany the longer LAD in the proximal AIS before terminating at the mid-AIS level. The septal and the diagonal branches were seen arising from the shorter LAD and longer LAD, respectively. As there was no significant coronary artery stenosis, the patient was managed conservatively and has been advised regular follow-up.

Dual LAD anomalies are extremely rare with a reported incidence of $0.03 \%-0.2 \%$. Twelve variants of dual LAD are described in the literature. ${ }^{1}$ Rather than the variant of the dual $\mathrm{LAD}$, the anatomy of dual LADs should be better described according to the clinical significance and risk stratification for the anomalous aortic origin of a coronary artery (AAOCA) from the inappropriate sinus of Valsalva (SOV). ${ }^{2}$ In the classification proposed by Cheezum et al, anomalous left coronary artery (ALCA) arising from the right SOV or anomalous right coronary artery arising from the left SOV or rarely, AAOCA from the 'noncoronary' SOV can further be classified based on the presence of one of the five course

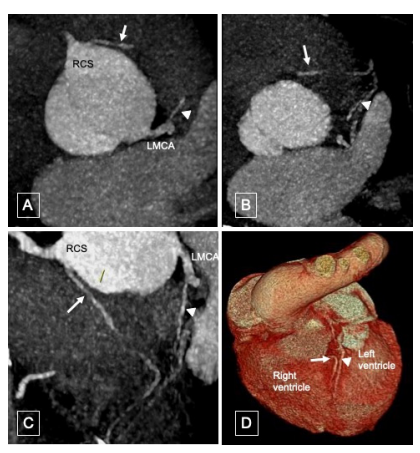

Figure 1 (A-C) CT angiography image at the level of the aortic root showing shorter left anterior descending (LAD) (white arrow) arising separately from the right coronary sinus (RCS) and longer LAD (white arrowhead) from the left main coronary artery (LMCA). (B) CT angiography image showing trans-septal course of the shorter LAD (arrow) . (D) Volume rendered image showing both the shorter LAD (white arrow) and longer LAD (white arrowhead) in the interventricular sulcus. subtypes, that is, interarterial, retroaortic, subpulmonic (intraconal or intraseptal), prepulmonic or retrocardiac. ${ }^{2}$ The risk of sudden cardiac death is highest for interarterial ALCA. Prepulmonic and retroaortic courses are usually asymptomatic. Trans-septal course has long been considered benign; however, recent literature reveals that upto one-fourth of these patients could develop adverse cardiac events. ${ }^{3}$

Our patient had a shorter LAD with an transseptal course. This could be a reason for the atypical chest pain she experienced; however, in view of the absence of significant stenosis in the longer LAD, she was managed conservatively. Recognition of such anomalies is crucial for risk stratification to plan percutaneous or surgical revascularisations and to avoid inadvertent injuries to the coronary arteries.

\section{Learning points}

- Dual left anterior descending (LAD) anomalies are extremely rare.

- The longer LAD arises from the left main coronary artery and the shorter LAD from the right coronary sinus in this unique variant of dual LAD.

- Recognition of such anomalies is crucial for risk stratification and to plan percutaneous or surgical revascularisations.

Contributors VO prepared, proofread and finalised the manuscript and the image. SNR prepared and finalised the manuscript and the image. KG and AS proofread and finalised the manuscript and the image.

Funding The authors have not declared a specific grant for this research from any funding agency in the public, commercial or not-for-profit sectors.

Competing interests None declared.

Patient consent for publication Obtained.

Provenance and peer review Not commissioned; externally peer reviewed.

\section{ORCID iDs}

Vineeta Ojha http://orcid.org/0000-0003-4371-5615 Kartik P Ganga http://orcid.org/0000-0002-5391-8531

\section{REFERENCES}

1 Al-Umairi RS, Al-Kindi FA, Al-Tai SA. A new variant of dual left anterior descending artery anomaly: type XI. Sultan Qaboos Univ Med J 2018;18:386-8.

2 Cheezum MK, Liberthson RR, Shah NR, et al. Anomalous Aortic Origin of a Coronary Artery From the Inappropriate Sinus of Valsalva. J Am Coll Cardiol 2017;69:1592-608.

3 Glushko T, Seifert R, Brown F, et al. Transseptal course of anomalous left main coronary artery originating from single right coronary orifice presenting as unstable angina. Radiol Case Rep 2018;13:549-54. 
Images in...

Copyright 2020 BMJ Publishing Group. All rights reserved. For permission to reuse any of this content visit https://www.bmj.com/company/products-services/rights-and-licensing/permissions/

BMJ Case Report Fellows may re-use this article for personal use and teaching without any further permission.

Become a Fellow of BMJ Case Reports today and you can:

- Submit as many cases as you like

- Enjoy fast sympathetic peer review and rapid publication of accepted articles

Access all the published articles

Re-use any of the published material for personal use and teaching without further permission

Customer Service

If you have any further queries about your subscription, please contact our customer services team on +44 (0) 2071111105 or via email at support@bmj.com.

Visit casereports.bmj.com for more articles like this and to become a Fellow 